\title{
A PÁRIZSI MEGÁLLAPODÁS HATÁSA AZ ÉGHAJLATVÁLTOZÁS ELLENI KÜZDELEMRE AZ EURÓPAI UNIÓBAN ÉS MAGYARORSZÁGON
}

\section{THE EFFECT OF THE PARIS AGREEMENT ON THE COMBAT AGAINST CLIMATE CHANGE IN THE EUROPEAN UNION AND HUNGARY}

\author{
Huszár András \\ osztályvezető, Innovációs és Technológiai Minisztérium Klímapolitikai Főosztály \\ andras.huszar@itm.gov.hu
}

\section{ÖSSZEFOGLALÁS}

\begin{abstract}
A 2015 decemberében létrehozott, majd alig egy évvel később, 2016 novemberében hatályba lépett Párizsi Megállapodás vitathatatlanul paradigmaváltást eredményez a nemzetközi klímapolitikában. Ennek a hatásai szükségszerűen érzékelhetőek regionális és helyi szinteken is, így az Európai Unióban és Magyarországon is. Ugyan a megállapodás keretében az államok által tett nemzetileg meghatározott hozzájárulások 2020-tól induló időtávokra vonatkoznak, az egyes részletszabályok kidolgozása, vagyis a megállapodás végrehajtására való felkészülés, valamint az új rezsim előírásaihoz történő alkalmazkodás mind a nemzetközi tárgyalásokon, mind regionális és nemzeti szinten már javában zajlik. Különösen igaz ez az Európai Unióra, és az Unió tagállamaként Magyarországra is. Jelen írás kísérletet tesz arra, hogy feltérképezze a Párizsi Megállapodás által a mitigációs részterületen hozott főbb változásokat és azok hatásait az EU, valamint Magyarország klímapolitikájára. Az új irányok megértéséhez a korábbi politika főbb vonalainak bemutatása is szükségesnek mutatkozik. Tekintettel azonban arra, hogy a 2004-es EU csatlakozás óta Magyarország klímapolitikája nagymértékben az EU-s szabályok által meghatározott, a két földrajzi egység e tekintetbeli különbözőségeit csak ott érinti a dolgozat, ahol az eltérésnek különös oka vagy jelentősége van.
\end{abstract}

\section{ABSTRACT}

The Paris Agreement, adopted in December 2015 and coming into force less than a year later in November 2016, has undisputedly resulted in a paradigm shift in international climate policy. Such a paradigm shift can inevitably be sensed at regional as well as local level both in the European Union and Hungary. However the timescale of the nationally determined contributions put forward by states under the Agreement only refer to the period after 2020, the preparation for the implementation of the Agreement, and the adaptation to the new regime has already been going on both at the international climate talks and at the regional and national level. It is particularly relevant to the European Union, including Hungary. This paper aims mapping the major changes in the so-called mitigation sector, introduced by the Paris Agreement, and its effect on the EU's and Hungary's climate policy. In order to better understand those changes it is 
also necessary to briefly mention the old policies. Due to the fact that since Hungary's accession to the EU in 2004, the Hungarian climate policy has been largely determined by EU regulations, the differences between the two geographical units will only be specified, where relevant.

Kulcsszavak: ENSZ Éghajlatváltozási Keretegyezmény, Párizsi Megállapodás, nemzetközi klímapolitika, Európai Unió, mitigáció, kibocsátáscsökkentés

Keywords: UN Framework Convention on Climate Change, Paris Agreement, international climate policy, European Union, mitigation, emission reduction

\section{BEVEZETÉS}

A nemzetközi és nemzeti klímapolitikákat (vagyis mindazon szabályok és cselekvések összességét, amelyek arra irányulnak, hogy az emberi tevékenység által rendkívüli mértékben felgyorsított éghajlatváltozás olyan szinten mérséklődjön, amely által a legveszélyesebb következmények elmaradnak, illetve a már elkerülhetetlen hatásokhoz a lehető legmegfelelőbben alkalmazkodni lehessen) mind politikai, mind részben jogi értelemben már ma is, de 2020-tól egyértelműen meghatározó Párizsi Megállapodás (a továbbiakban: megállapodás) pontos hatásai nehezen mérhetőek fel. Egyfelől látható, hogy még azelőtt, hogy a megállapodás meglehetősen általános rendelkezéseinek a konkrét cselekvésszintü végrehajtását megkönnyítő végrehajtási szabályait, az ún. párizsi munkaprogram keretében kidolgoznák és elfogadnák a megállapodásban részes felek, a megállapodás már ma is számos helyen hivatkozási alap új jogszabályjavaslatok vagy egyéb politikai dokumentumok, programok elfogadásakor. Másfelől az is érzékelhető, hogy az a változási folyamat, amely épp a megállapodás megszületésének egyik, ha nem a legfőbb katalizátora volt, nevezetesen a nem állami szereplők, kiváltképp egyes üzleti és más nem kormányzati politikai szereplők döntéseiben és cselekvéseiben tapasztalható változások a megállapodástól függetlenül terelnek más mederbe folyamatokat. Továbbá, a megállapodás szövege épp olyan mértékben általános, tág megfogalmazásokkal él, amelyek meglehetősen tág teret hagynak arra vonatkozóan, hogy a világban történt folyamatokat azok hatásaiként láthassuk.

\section{A Párizsi Megállapodás rövid, általános bemutatása}

A megállapodás sorban a harmadik, az ENSZ égisze alatt létrehozott és hatályba lépett nemzetközi klímapolitikai tárgyú szerződés. Az első az 1992-ben létrehozott, és 1994. március 21-én hatályba lépett Éghajlatváltozási Keretegyezmény (a továbbiakban: keretegyezmény) volt (URL1, URL2). A keretegyezmény határozza meg mind a mai napig a nemzetközi klímapolitikai tárgyalások és ezen keresztül 
a globális klímapolitika legalapvetőbb kereteit (Klein et al., 2017). Ez olyannyira igaz, hogy magát a megállapodást is a keretegyezmény részes felei konferenciájának (Conference of the Parties, COP) 21. ülésszakán hozták létre, 2015. december 12-én. A megállapodás preambuluma is rögzíti, hogy a megállapodás részes felei a keretegyezmény célkitűzésének elérése érdekében és annak elvei alapján állapodtak meg. Ezek a hivatkozott és a keretegyezmény által meghatározott elvek (ilyen különösen a méltányosság elve, és a közös, de megkülönböztetett felelösség és az eltérő képességek elve, tekintettel az eltérő nemzeti körülményekre) áthatják a globális klímapolitika szabályrendszerét, és megalapozzák az egyes felektől elvárt intézkedések közötti differenciálást.

A differenciálás kérdéskörének részletes tárgyalása nélkül, ezen elv legtisztább érvényre jutása látható a sorrendben második jelentős nemzetközi klímapolitikai instrumentum, az 1997 decemberében létrehozott, de csak 2005. február 16-án hatályba lépett keretegyezmény Kiotói Jegyzökönyvének (a továbbiakban: jegyzőkönyv) példáján (Torvanger et al., 2004). A jegyzőkönyv a részes felei közül ugyanis a keretegyezmény által alkalmazott, annak részes feleit többfelé osztó rendelkezései alapján, kizárólag a keretegyezmény I. mellékletében szereplő államok számára írt elő jogilag kötelező szabályokat a kibocsátáscsökkentés terén. A megállapodás ehhez képest teljesen eltérő megközelítést alkalmaz a differenciálás tekintetében. Egyrészt - elhagyva a jegyzőkönyv által használt, az I. mellékletben szereplö és az I. mellékletben nem szereplő felek megkülönböztetést, és áttérve a kevésbé világos fejlett és fejlődő ország terminológiára - bizonyos területeken egy platformra hozza a részes feleit azáltal, hogy valamennyiükre egyformán vonatkozó kötelezettségeket állapít meg (például 4. cikkely 2. pont). Másrészről a jegyzőkönyvnél is szélesebb körü differenciálásra ad lehetőséget azáltal, hogy a részes feleire bízza például a saját nemzetileg meghatározott hozzájárulásaik kidolgozását. Ezekre vonatkozóan tartalmi rendelkezéseket csak annyiban határoz meg, hogy egy részes fél által később benyújtott hozzájárulásnak, az általa korábban kommunikált hozzájárulásnál ambiciózusabbnak kell lennie. A megállapodás a jegyzőkönyvhöz képest tehát az úgynevezett alulról épitkezést helyezi a középpontba, érvényre juttatva ezáltal azt a koncepciót, ami szerint az adott fél határozza meg saját konkrét teendőit (Pickering, 2015).

A számtalan egyéb különbözőség mellett a megállapodás előrelépést jelent anynyiban is a jegyzőkönyvhöz képest, hogy a klímapolitikának a kibocsátáscsökkentésnél szélesebb spektrumán alkot bizonyos szabályokat. Ezeket összefoglalóan nevezhetjük a klímapolitika fö területeinek. Ilyen a pusztán a kibocsátások csökkentésén túlmutató mitigáció, az éghajlatváltozás már elkerülhetetlen hatásaihoz való alkalmazkodás, és a két előbbi területen történő cselekvések végrehajtását előmozdító eszközök, a klímafinanszírozás, a technológiafejlesztés és -transzfer, a kapacitásépítés, valamint a végrehajtás rendszeres értékelése. A következőkben a mitigáció tématerületén keresztül vizsgáljuk meg a megállapodás hatását az EU-s és magyar politikákra. 


\section{A MITIGÁCIÓ MIBENLÉTÉRŌL}

E részterület szélesebb spektrumot fed le, mint az üvegházhatású gázok (a továbbiakban: ÜHG) kibocsátásának közvetlen csökkentése. A „mérséklésnek” is fordítható tevékenység ugyanis mindazon erőfeszítésekre utal, amelyek az éghajlati rendszerre gyakorolt negatív emberi hatások csökkentését irányozzák elő. Ebbe a körbe tartozik az úgynevezett nyelő kapacitások növelése, például szén-dioxid megkötésére képes növényzet telepítése útján, amely „nettó kibocsátáscsökkenéssel" jár. De ide érthető az energiahatékonyság növelése, sőt a legszélesebb értelemben a társadalmi tudatosság növelése is, ami olyan döntésekre és cselekvésekre ösztönöz, amelyek a természetre való lehető legkisebb negatív emberi ráhatás felé mutatnak (Lackner et al., 2017).

Az éghajlat természetes változásának felgyorsulását és később akár kontrollálhatatlanná válását eredményező antropogén, vagyis emberi eredetű ráhatást elsősorban az ÜHG-k rendkívüli mértékü kibocsátása eredményezi. Emiatt elengedhetetlen ennek a problémának a kezelése, ha mindenekelőtt ezt a hatást mérsékeljük, és radikálisan csökkentjük az ÜHG-kibocsátásokat, kiegészítve ezt a nyelő kapacitások növelésével, és az általunk használt eszközök energiahatékonyságának növelésével. Ráadásul az ilyen típusú folyamatok relatíve jól nyomon követhetőek. Egy adott, jól körülhatárolt földrajzi egység, például egy ország területén egyre pontosabb módszerek léteznek arra vonatkozóan, hogy a különböző források által kibocsátott ÜHG-kibocsátásokat meghatározzák, és azokat folyamatukban nyomon kövessék. Vagyis klímapolitikai szabályozás szempontjából jól kezelhető, mérhető területről van szó.

\section{KIBOCSÁTÁSCSÖKKENTÉS A KIOTÓI JEGYZŐKÖNYV IDŐSZAKÁBAN}

\section{A Kiotói Jegyzőkönyv célrendszere}

A jegyzőkönyv (1992), amelynek az EU és összes tagállama, így Magyarország is részes fele, a fentiekből kifolyólag konkrét, számszerü kibocsátáscsökkentési célszámokat írt elő. A jegyzőkönyv a 3. cikkében a keretegyezmény I. mellékletében szereplő államok számára, legalább átlagosan 5\%-os kibocsátáscsökkentést irányozott elő az 1990-es bázisévhez képest, a jegyzőkönyv B mellékletében pedig az egyes részes felei által saját maguk tekintetében megjelölt bázisévhez képest rendelt egyenkénti csökkentési célokat. Az EU akkori tagállamai számára együttesen 8\%-os csökkentést írt elő az 1990-es bázisévhez képest az első kötelezettségvállalási időszak végére. Magyarország esetén, amely még nem EU-tagként tette meg a vállalását, a cél 6\%-os mérséklés volt az 1985-87-es évek kibocsátási átlagához képest, ugyancsak az úgynevezett első kötelezettségvállalási időszak alatt, amely 2008-tól kezdődött és 2012-ig tartott. 


\section{A Kiotói Jegyzőkönyv eszközrendszere}

A jegyzőkönyv lehetőséget adott úgynevezett rugalmassági mechanizmusok használatára is a kibocsátáscsökkentési célok elérése érdekében. Felismerve, hogy a kibocsátások csökkentése a Föld bármely pontján ugyanolyan pozitív hatással bír a globális éghajlatváltozásra, e mechanizmusok azt tették lehetôvé, hogy a részes felek (vagyis nem kizárólag a vállalást tevő I. mellékletben szereplő államok) együttműködjenek három lehetséges módon: a nemzetközi kvótakereskedelem, együttes teljesítés (Joint Implementation, JI), valamint a tiszta fejlesztési mechanizmus (Clean Development Mechanism, CDM) útján. A kvótakereskedelem lényege, hogy az ÜHG kibocsátási jogokat pénzben kifejezhető értékủ kibocsátási egységekké változtatja, és lehetővé teszi az ezekkel való kereskedést. A kibocsátáscsökkentési elöírást túlteljesítő, és így „kvótatöbblettel” rendelkezők eladhatnak ilyen jogosultságokat azoknak, akik nem tudták vagy csak drágábban tudták volna csökkenteni a kibocsátásaikat. A JI lényege, hogy egy, a keretegyezmény I. mellékletében szereplő ország egy másik I. mellékletben szereplő ország területén hajt végre olyan beruházást, amelynek eredményeként kibocsátáscsökkentést ér el, és ezt a saját vállalásaiba számítja bele. Ezzel szemben a CDM egy, a keretegyezmény I. mellékletében szereplő ország által egy I. mellékletben nem szereplő ország területén végrehajtott hasonló beruházását, és az abból eredő elszámolást jelenti.

\section{Az EU és Magyarország mitigációs politikája a Kiotói Jegyzőkönyv végrehajtására}

Az Európai Unió és Magyarország is használta a fent részletezett eszközöket a vállalásainak teljesítése érdekében (Rüsch, 2008). Elöljáróban fontos megjegyezni, hogy az EU már a jegyzökönyv alatt vállalt kibocsátáscsökkentését is közösen teljesítette, amire a jegyzökönyv 3. és 4. cikke adott felhatalmazást. Ennek a megoldásnak a lényege, hogy az EU tagállamai egy aggregát kibocsátáscsökkentési számot vállalnak, közösen, ám annak országonkénti „leosztását” belső jogszabályok szerint rendezik. Az ilyen típusú „erőfeszítés-megosztással” elérhető, hogy olyan országokban, ahol a csökkentésnek nagyobb költséghatékony potenciálja áll rendelkezésre az átlagos számnál nagyobb, míg más országokban az átlagos vállalásnál kisebb csökkentést, esetleg növekedést engedjenek meg. Az EU ennek megfelelően már 2005-től 2007-ig kísérleti jelleggel létrehozta és müködtette a vállalatközi kvótakereskedelmi piacát, az Európai emisszió-kereskedelmi rendszert (European Union Emission Trading System, EU ETS). Az EU ETS második kereskedési időszaka 2008-tól 2012-ig már ,élesben” szolgálta a jegyzőkönyv céljainak teljesülését, és az EU tagállamain felül Izland, Norvégia és Liechtenstein is csatlakozott hozzá. Tekintettel arra, hogy a csökkentés nagy részét az energetikai szektor tudta végrehajtani, az EU ETS hatálya a viszonylag könnyen beazonosít- 
ható és nyomon követhető erőművekre vonatkozott. Ugyanakkor ambiciózusabb kibocsátáscsökkentési vállalások teljesítéséhez más, egyéb szektorokra vonatkozó előírások voltak később szükségesek.

Magyarország az EU tagjaként részt vett az EU ETS-ben, emellett a bázisévéhez képest jelentős mértékủ kibocsátáscsökkenés és -csökkentés eredményeként élt a többletkvóták eladásának jogával is. Emellett az ENSZ Éghajlatváltozási Keretegyezménye és annak Kiotói Jegyzőkönyve végrehajtási keretrendszeréről szóló 2007. évi LX. tv. előírásai szerint, az ún. VAHAVA-projekt (VÁltozás - HAtás - VÁlaszadás) szakmai eredményeire építve elkészítette az ország első Nemzeti Éghajlatváltozási Stratégiáját (a továbbiakban: NÉS-1) a 2008-2025 közötti időszakra vonatkozóan. A NÉS-1 Magyarország középtávú klímapolitikájának három fö cselekvési irányát jelölte ki:

a) az uniós és nemzetközi követelményeknek megfelelően intézkedéseket az éghajlatváltozást kiváltó gázok kibocsátásának csökkentése és növekedésének megelözése érdekében,

b) a már elkerülhetetlen éghajlatváltozás kedvezőtlen ökológiai és társadalmi-gazdasági hatásai elleni védekezést, az éghajlatváltozás következményeihez való alkalmazkodóképesség javítását, valamint

c) az éghajlatváltozás társadalmi tudatosítását és a klímatudatosság erősítését.

\section{A kiotói rendszer fóbb hiányosságai}

Habár mind Magyarország, mind az EU és tagállamai sikeresen teljesítették, sőt túlteljesítették a jegyzőkönyvben tett vállalásaikat (a teljes EU csökkentése kb. 19\% százalék volt a bázisévhez képest 2012 végére), a jegyzőkönyv globális szintü elégtelensége az éghajlatváltozás által kiváltott komplex problémarendszernek pusztán a mitigációs oldalról történő korlátozott mértékü kezelésére már korán kiderült (Rosen, 2015). Egyrészt a korábban említettek szerint a jegyzőkönyv kizárólag a keretegyezmény I. mellékletében szereplő fejlett országok számára írt elő kötelező ÜHG-csökkentési (némely ország, például Ausztrália vagy Izland esetén maximális ÜHG-kibocsátásnövekedési) számokat. Holott a korábban valóban fejletlenebb és ezáltal alacsonyabb ÜHG-kibocsátású országok közül jó néhány a jegyzőkönyv hatálybalépésének időszakára megsokszorozta és folyamatosan növelte kibocsátásait (a keretegyezmény I. mellékletében nem szereplő Kína kb. 2007 óta, megelőzve az Amerikai Egyesült Államokat, a legnagyobb abszolút ÜHG-kibocsátó ország). Ebből pedig az következik, hogy ezen országok „nem csökkentése”, sőt kibocsátásnövelése nem teszi lehetővé a probléma hosszú távú kezelését. Másrészt a jegyzőkönyv ugyan előírt kibocsátáscsökkentést egy bizonyos időtávon belül, de nem biztosította az időszakok folytonosságát, pusztán arról rendelkezett, hogy legalább hét évvel az első kötelezettségvállalási időszak vége előtt meg kell kezdeni a tárgyalásokat egy 
következő kötelezettségvállalási időszak részleteiről. A harmadik fő probléma a jegyzökönyvvel, hogy nem tartalmazott a kibocsátáscsökkentés tekintetében egy globális végcélt. Nem mondta ki, hogy mi lenne az a kibocsátáscsökkentési cél, amely felé az országoknak törekedniük kell. Összefoglalva, habár a keretegyezmény végrehajtására született, nem konkretizálta a keretegyezmény meglehetősen általános célkitűzését. A megállapodásnak többek között a fenti kihívásokra kellett választ adnia.

\section{A PÁRIZSI MEGÁLLAPODÁS MITIGÁCIÓS RENDELKEZÉSEI}

Mielőtt a megállapodás mitigációs rendelkezéseiről szólnánk, két dolgot érdemes rögzítenünk. Egyrészt a jegyzőkönyv első kötelezettségvállalási időszakának végétől (2013-tól) a megállapodás alatt tett vállalások időkeretének megkezdődéséig (2020-tól) nincs hatályos, nemzetközi jogi értelemben kötelező jogi dokumentum, amely kibocsátáscsökkentésre kötelezné az országokat. Ettől függetlenül számos helyen, így az Európai Unióban és Magyarországon is vannak hatályos jogszabályok, amelyek ilyen típusú célokat, intézkedéseket, elöírásokat tartalmaznak. Ezek a fentebb már bemutatott intézkedések szerves továbbfejlesztései és kiterjesztései. Másrészt a jelen tanulmány keretei nem teszik lehetővé a megállapodás mitigációs rendelkezéseivel kapcsolatos valamennyi körülmény részletes ismertetését, így az alábbi taglalás szükségképpen csak leszükítő és összefoglaló jellegű lehet.

\section{A Párizsi Megállapodás mitigációs célrendszere}

\section{A globális hömérsékleti cél(ok)}

A megállapodás a jegyzőkönyvhöz képest egy átfogóbb célrendszert tartalmazó dokumentum. Először is rögzíti, hogy a keretegyezmény általános célját kívánja előmozdítani, többek között a globális átlaghőmérséklet-emelkedésnek az iparosodás előtti szinthez képest jóval 2 Celsius-fok alatt tartásával, törekedve arra, hogy a melegedés ne haladja meg a 1,5 Celsius-fokot (2. cikkely 1. a) pont). Ez az ún. hőmérsékleti cél(ok) pontosan kijelöli a mitigációs erőfeszítések végső értelmét. A 2 Celsius-fokos cél világosan kijelöli azt a mércét, amelyhez a globális kibocsátáscsökkentési erőfeszítéseket mérni lehet. Meg lehet mondani, hogy a megállapodásban részes felek által tett vállalások összességében elegendőek-e a cél tartásához. A megállapodás korábban már említett, alulról építkező jellegéből adódóan ugyanakkor a részes feleire bízza az ehhez a célhoz való hozzájárulásaik kidolgozását, vagyis nem tartalmaz egyes országokra lebontott célszámokat. 


\section{Az emberi eredetü forrásokból származó kibocsátások és a nyelök általi elnyelések közötti egyensúly}

A jelzett „hőmérsékleti célok” elérése érdekében a megállapodás részes felei a globális ÜHG-kibocsátások tetőpontját minél előbb el kell hogy érjék, majd radikális csökkentést kell végrehajtaniuk annak érdekében, hogy a 21. század második felére megvalósuljon az egyensúly az emberi eredetủ forrásokból származó kibocsátások és a nyelők általi elnyelések között. A megállapodás 4. cikkely 1. pontjának ezen rendelkezése újabb hosszú távú célt rögzít a részes felei számára a mitigáció részterületén. A kibocsátások folyamatos csökkentésének egy olyan kibocsátási szint elérése a célja, amely a század második felében globális szinten nem haladja meg a nyelö kapacitásokat, vagyis megvalósul az úgynevezett nettó „,karbonsemlegesség" állapota. Ez a cél is alkalmas mérce a kibocsátáscsökkentési vállalások összességének megfelelöségét illetően. Más kérdés, hogy az egyes részes felek vállalásainak megfelelőségét ezekhez a célokhoz (a hőmérsékleti cél[ok]hoz és az egyensúly eléréséhez) mérni meglehetősen nehézkes, mert a szükséges globális kibocsátáscsökkentés nincs „leosztva” az egyes részes felek között (egyedüli támpontot e tekintetben a közös, de megkülönböztetett felelösség elve adhat, de ez alapján sem nyilvánvaló az egyes részes felekre jutó hányad). Ráadásul, ahogy a továbbiakból kiderül, a részes felek csak saját maguk dolgozhatják ki a saját hozzájárulásaikat, és csak ők módosíthatják azokat. Vagyis, annak ellenére, hogy a célokhoz képest a vállalások összhatása jól mérhető, kizárólag a részes felekre van bízva, hogy milyen mértékben veszik figyelembe az esetleges eltéréseket.

\section{A nemzetileg meghatározott hozzájárulások}

A megállapodás 4. cikkének 2. pontja rögzíti a valamennyi részes félre vonatkozó legfőbb kötelezettséget; kidolgoznak, a nemzetközi közösség felé kommunikálnak, és fenntartanak egymást követő nemzetileg meghatározott hozzájárulásokat (Nationally Determined Contributions, NDC) amelyeket el akarnak érni. Ez minden részes félre nézve kötelezö. A 4. cikkely szól továbbá arról, hogy a felek az NDC-kben megfogalmazott céljaik eléréséhez szükséges belföldi intézkedéseket hoznak. Rögzíti továbbá, hogy a fejlett országoknak a továbbiakban is élen kell járniuk a vállalások tekintetében azáltal, hogy a jegyzőkönyv alatt tett vállalásokhoz hasonlóan a teljes gazdaságukra kiterjedő kibocsátáscsökkentési célokat fogalmaznak meg. Ez azt jelenti, hogy a megállapodás a fejlett országok viszonylatában inkorporálja a jegyzőkönyv által elöírtakat, vagyis e tekintetben a jegyzőkönyv folytatásaként értelmezhetö. Több más különbség mellett ugyanakkor rendkívül fontos változás, hogy az egymást követő NDC-ket ötévente újra kommunikálni kell az ENSZ felé, és ezeknek a korábbihoz képest előrehaladást kell mutatniuk. A megállapodás a jegyzőkönyvhöz képest ezáltal egy ún. „ambícióciklust" hoz létre, amely biztosítja, hogy időről időre, külön tárgyalás és megegyezés nélkül, a részes feleknek felül kelljen vizsgálniuk, és felfelé kelljen 
módosítaniuk az NDC-jeiket. Ez a rendelkezés garantálja a megállapodás tartósságát, időtállóságát, és lehetőséget teremt az NDC-knek a hosszú távú célokhoz való folyamatos igazítására. A hozzáigazítás támpontjaként a megállapodás 14. cikkelye által létrehozott ún. globális értékelések (Global Stocktake, GST) végkimenetele szolgál majd. Az első ilyenre 2023-ban kerül majd sor, a részletszabályairól jelenleg is zajlanak a tárgyalások. A részes felek beszámolásra kötelezettek, és felelösek az NDC-jükben foglaltakkal kapcsolatban, lehetőséget kapnak ugyanakkor arra, hogy - a jegyzőkönyv rendelkezéseihez hasonlóan - más részes felekkel közösen tegyenek hozzájárulásokat. A megállapodás 4. cikkelyének utolsó pontja arra biztatja (vagyis nem kötelezi) a részes feleket, hogy hosszú távú, alacsony ÜHG-kibocsátású fejlesztési stratégiákat dolgozzanak ki és kommunikáljanak, figyelemmel a megállapodás 2. cikkelyében rögzített célokra, valamint a közös, megkülönböztetett felelősség keretegyezményben rögzített elvére.

\section{A Párizsi Megállapodás mitigációs együttmúködési eszközrendszere}

A nemzetközi tárgyalások során részben a sokszor tapasztalt különböző visszaélések $(\mathrm{PwC}, 2011)$ részben a megállapodás teljesen eltérö természete miatt, a tárgyaló felek egyetértettek abban, hogy a jegyzőkönyv alatt bevezetett JI és CDM a megállapodás alatt változatlanul nem élnek tovább. Arról egyelőre vita van, hogy az azokban szerzett tapasztalatokra mennyire építsen egy új rezsim. A megállapodás ugyanis rendkívül általánosan szól a mitigációs vállalások részes felek közötti együttműködés általi teljesítéséről. Egyrészt az 5. cikkelyben lehetőséget teremt ilyen együttműködésre, amelynek során nemzetközileg átruházható mitigációs eredményekről (internationally transferred mitigation outcomes, ITMO) beszél. Ez a terminológia egyszerre fedi le a korábbi nemzetközi kvótakereskedelem, a JI- és CDM-intézményeket, de mégsem tartalmaz kellő konkrétumot ilyen programok végrehajtásához. Ennek kidolgozása a további tárgyalásokra marad. Ugyancsak az 5. cikkely hozza létre azt a „mechanizmust”, amely hozzájárul az ÜHG-mitigációhoz, illetve szól a „nem piaci” megközelítések fontosságáról, amelyek szintén hozzájárulhatnak az NDC-k teljesítéséhez. Mindezen végrehajtást segítő eszközök részletszabályai jelenleg is tárgyalás alatt állnak.

\section{AZ EURÓPAI UNIÓ ÉS MAGYARORSZÁG KLIIMAPOLITIKÁJÁNAK ALAKULÁSA A PÁRIZSI MEGÁLLAPODÁS HATÁSÁRA}

\section{Az EU előzetes vállalásai}

A megállapodás megkötéséhez vezető tárgyalások egy pontján, a 2013-as varsói COP-on megállapodás született arról, hogy a részes felek 2015 első negyedévében bejelentik elözetes, nemzetileg meghatározott hozzájárulásaikat (Intended 
Nationally Determined Contribution, a továbbiakban: INDC). Az EU a 2014 októberében, az Európai Tanács által elfogadott 2030-as klíma- és energiapolitikai keret (a továbbiakban: 2030-as keret) alapján összeállított INDC-jét 2015. március 6-án kommunikálta a keretegyezmény titkársága felé. Ebben az EU és tagállamai közösen legalább 40\%-os kibocsátáscsökkentést vállalnak az 1990-es bázisévhez képest 2030-ig. A benyújtott INDC rögzíti, hogy az EU ezen vállalása jelentős elörelépést mutat a korábbi, 2020 -ig vállalt 20\%-os kibocsátáscsökkentéshez képest, összhangban van a fejlett országok csoportja számára 2050-ig ajánlott 80-95\%-os hosszú távú kibocsátáscsökkentési céllal, és figyelembe veszi a globális kibocsátások 2050-re való megfelezésének szükséges célját is. Vagyis az EU a közös, de megkülönböztetett felelősség elvét is figyelembe véve kellően ambiciózusnak tartja a benyújtott INDC-jét. Az EU INDC-je a megállapodás hatálybalépésével az 1/CP.21 COP döntés értelmében automatikusan az EU első NDC-jévé vált.

\section{Az EU-vállalások végrehajtásának eszközei}

Az EU a jegyzőkönyv Dohai Módosítása által létrehozott második kötelezettségvállalási időszakának hatályba nem lépése ellenére tovább bővítette a klímapolitikai jogszabályrendszerét. A 2020-ra vállalt 20\%-os kibocsátáscsökkentés elérése érdekében tovább fejlesztette az EU ETS-rendszert, amely még radikálisabb kibocsátáscsökkentést eredményezett, illetve elfogadta az ún. erőfeszítés-megosztási határozatot (Effort Sharing Decision, ESD), amely az EU ETS által nem lefedett szektorok (közlekedés, épületek, mezőgazdaság, hulladék) vonatkozásában határozott meg tagállami kibocsátáscsökkentési célszámokat. Az EU INDC rögzíti, hogy a legalább 40\%-os cél elérése érdekében az EU ezen jogi instrumentumok további szigorításával kíván előrelépni. A 2030-as keret tartalmazta ennek a szigorításnak az alapelemeit; az ETS-szektorban 43\%-os csökkentést kell elérni 2030-ig a 2005-ös bázishoz képest, míg a nem ETS-szektorokban 30\%-os csökkentést szintén a 2005-ös bázishoz képest. A kettő összeadása eredményez 40\%-os összkibocsátás-csökkenést az 1990-es bázishoz képest. Az ezek részleteit tartalmazó jogszabály-módosító csomagokat az Európai Bizottság benyújtotta, és hosszas tárgyalások után az Európai Unió Tanácsa és az Európai Parlament is elfogadta azokat. Így kijelenthető, hogy ami a jogszabályi feltételeket illeti, az EU készen áll az első NDC-jében tett vállalásainak végrehajtására.

\section{Magyar klímapolitika Párizs után}

Magyarország aktívan részt vesz az EU belső és nemzetközi klímapolitikájának alakításában. A fent említett, már elfogadott EU-s jogszabályok végrehajtása által járul hozzá a közös teljesítés sikeréhez. Ezenfelül a magyar kormány által elfogadott, és az Országgyűlés elé elfogadásra benyújtott második Nemzeti Éghajlat- 
változási Stratégia (a továbbiakban: NÉS-2) teljes mértékben figyelembe veszi a megállapodás rendelkezéseit, azoknak megfelelően készült. A tervezet tartalmaz többek között egy hosszú távú kibocsátáscsökkentési stratégiát is, amely 2050re vonatkozó kitekintéssel határoz meg kibocsátáscsökkentési tartományokat. A NÉS-2 mellett a következő években átgondolásra érdemes további, a mitigáción akár túlmutató eszközök kidolgozása és elfogadása, amelyek hozzájárulhatnak a megállapodás magyarországi végrehajtásához. Végül, de nem utolsósorban érdemes megemlékezni a nem országos szintű, helyi közösségek által tett kibocsátáscsökkentési vállalásokról is. Ilyen például a jelenleg is zajló megyei és települési klímastratégiák kidolgozásának programja, amelynek során például a megyék és a települések saját magukra nézve dolgoznak ki olyan klímapolitikai terveket, amelyek mitigációs vállalásokat is tartalmaznak (például Budapest a 2018. április 25-én elfogadott klímastratégiájában 2030-ra 15\%-os csökkentést vállal a 2015-ös év bázisához képest) (URL3).

\section{ÖSSZEFOGLALÁS}

A fentiekben kifejtettekből arra a következtetésre juthatunk, hogy a megállapodás elfogadása az Európai Unió és benne Magyarország mitigációs politikáját nem helyezi radikálisan új pályára. Inkább úgy tetszik, hogy a megállapodás által elöírtak megerősítik és továbblépésre ösztönzik a jegyzőkönyv által hagyott ürben önállóan továbbvitt mitigációs politikát, amely így új lendületet kap, immár ismét nemzetközi szabályok által megtámogatva. A megállapodás valódi újítása, hogy jól mérhető globális célokat tűz a részes felei elé, és az ezekhez vezető hozzájárulásaik folyamatos mérésére kényszeríti őket, kellő motivációt biztosít az EU és Magyarország számára is, hogy ne térhessen le arról az útról, amelyet a mindinkább ambiciózus kibocsátáscsökkentések terén már megkezdett. Az EU átfogó jogszabályi környezete - a tökéletestől természetesen messze elmaradva - alkalmas lehet az NDC-jében vállalt célok elérésére. A mindenkori ambíciószint meghatározása pedig politikai döntés kérdésének tűnik a folyamatosan fejlődő technológiai keretek között. Szem előtt kell tartanunk ugyanakkor, hogy a megállapodás létfontosságú céljainak teljesüléséhez önmagában az Európai Unió bármilyen mértékü kibocsátáscsökkentési előírásai legfeljebb csak részben járulhatnak hozzá. Régóta köztudott, hogy a jelenleg benyújtott NDC-k összhatása messze elmarad a megállapodás céljainak eléréséhez szükséges pályától (UNEP, 2017). Az elkövetkező időszak egyik legnagyobb kérdése, hogy a részes felek hogyan kezelik ezt az elég széles és mély „szakadékot”. Az ezzel kapcsolatos tárgyalások végkimenetele minden bizonnyal komoly hatással lesz az EU és Magyarország klímapolitikájának jövőjére is. 


\section{IRODALOM}

Delbeke, J. - Vis, P. (eds.) (2016): EU Climate Policy Explained. European Union, https://ec.europa.eu/clima/sites/clima/files/eu_climate_policy_explained_en.pdf

Faragó T. (2016): A párizsi klímatárgyalások eredményei. Magyar Energetika, 1, 8-12. http://real. mtak.hu/62026/1/Parizs_Megallapodas_M_E_u.pdf

Kis A. et al. (2000): Magyarország várható hasznai és költségei a Kiotói Jegyzökönyv „,közös megvalósitás” mechanizmusához kapcsolódóan. MAKK, http://makk.zpok.hu/files/MAKK\%20 JI\%2007-2000_1.pdf

Klein, D. et al. (2017): The Paris Agreement on Climate Change, Oxford University Press

Lackner M. et al. (2017): Introduction to Climate Change Mitigation. In: Chen, W.-Y. - Suzuki, T. - Lackner, M. (eds.): Handbook of Climate Change Mitigation and Adaptation. Springer DOI 10.1007/978-3-319-14409-2_1, https://www.researchgate.net/publication/312007628_Introduction_to_Climate_Change_Mitigation

Pickering, J. (2015): Top-down Proposals for Sharing the Global Climate Policy Effort Fairly: Lost in Translation in a Bottom-up World? Institute for Governance \& Policy Analysis, http:// www.governanceinstitute.edu.au/magma/media/upload/ckeditor/files/Top-down $\% 20 \mathrm{vs} \% 20$ bottom-up\%20-\%20working\%20paper\%20version\%201(1).pdf

PwC - PricewaterhouseCoopers (2011): The Green Fraud Guide. https://www.pwc.co.uk/assets/ pdf/greenfraud.pdf

Rosen, A. M. (2015): The Wrong Solution at the Right Time: The Failure of the Kyoto Protocol on Climate Change, Politics \& Policy, 43, 1, 30-58. DOI: 10.1111/polp.12105, https://onlinelibrary. wiley.com/doi/full/10.1111/polp.12105

Rüsch, J. (2008): Country Profiles for CDM and JI Project Development: Europe and Central Asia, http://www.bmub.bund.de/fileadmin/bmu-import/files/pdfs/allgemein/application/pdf/ country_profiles.pdf

Torvanger, A. - Godal, O. (2004): An Evaluation of Pre-Kyoto Differentiation Proposals for National Greenhouse Gas Abatement Targets. International Environmental Agreements: Politics, Law and Economics, 4, 1, 65-91. https://doi.org/10.1023/B:INEA.0000019056.43577.b2

UNEP (2017): The Emissions Gap Report 2017 - A UN Environment Synthesis Report. https:// wedocs.unep.org/bitstream/handle/20.500.11822/22070/EGR_2017.pdf

URL1: https://unfccc.int/process-and-meetings/the-paris-agreement/the-paris-agreement

URL2: https://treaties.un.org/Pages/ViewDetails.aspx?src=TREATY\&mtdsg_no=XXVII-7$\mathrm{d} \&$ chapter $=27 \&$ clang $=$ en

URL3: http://budapest.hu/Documents/klimastrategia/Bp_Klimastrategi\%C3\%A1ja_vegleges_ KGY\%20elfogadott.pdf 